\title{
Alumeda solorzanokraemerae sp. nov. from the Miocene Mexican Amber (Hemiptera: Heteroptera, Reduviidae, Emesinae)
}

\author{
Yuri A. Popov ${ }^{1, *}$ \\ ${ }^{1}$ Borissiak Paleontological Institute, Russian Academy of Sciences, Profsoyuznaya str. 123, 117997 Moscow Russia. \\ *popovpin@gmail.com
}

\begin{abstract}
A new fossil emesine reduviid from the Middle Miocene Mexican amber from the Simojovel-Alumeda solorzanokraemerae sp. nov. - is described and illustrated. This is the second record of Reduviidae: Emesinae in Mexican amber and the fifth from the New World contemporaneous (Dominican amber) fossil resin.
\end{abstract}

Keywords: Alumeda, Heteroptera, Reduviidae, Emesinae, Mexican amber.

\section{Resumen}

Se describe e ilustra un nuevo, reduviido emesine, fósil del ámbar Mexicano del Mioceno Temprano de Simojovel - $\underline{\text { Alumeda }}$ solorzanokraemerae sp. nov. -. Este es el segundo registro de Reduviidae: Emesinae en ámbar Mexicano y el quinto de la resina fosil contemporánea del Nuevo Mundo (ámbar Dominicano).

Palabras clave: Alumeda, Heteroptera, Reduviidae, Emesinae, ámbar mexicano.

\section{Introduction}

The purpose of the present paper is to put on record in Mexican amber a new species from a remarkable extinct genus Alumeda Popov whose three species were earlier described from Dominican amber (Popov, 1989). The most famous resin of this area is Dominican and Mexican amber, the latter also called "Chiapas amber", both being of Middle Miocene age (Solórzano Kraemer, 2007). Both resins originated from a leguminous tree of the genus Hymenaea (Poinar, 1999; Langenheim, 1966). Mexican amber originated in Tuxtla Gutierrez, Chiapas in southernmost Mexico, bordered to the south by Guatemala. Most amber deposits occur in the northern mountain ranges, referred to as Chiapas highlands, and the majority of amber mines are located in the Simojovel area (Poinar, 1992). Previously, the Simojovel Formation (La Quinta) was considered to be in between Oligocene-Miocene (Frost and Langenheim 1974; Berggren and Van Couvering, 1974). Recently the age of the Simojovel Formation, like that of all other amber localities, has been established as Early-Middle Miocene, with an age of 15-20 million years (Solórzano Kraemer, 2007, 2010).

In Mexican amber quite a lot of insects have been described and mentioned (see appendix in Solórzano Kraemer, 2010). Our current knowledge about heteropteran bugs from Mexican amber is still poor. The first description of a real bug belonging to the family Ceratocombidae (Ceratocombus hurdi Wyg.) was published by Wygodzinsky (1959). Cobben (1971) established a new leptopodomorphan subfamily Leptosaldinae for a peculiar Leptosalda chiapensis Cobben. Thomas (1988) described the first burrower bug (Cydnidae) of the plesiomorphic subfamily Amnestinae from the Western Hemisphere Amnestus guapinolinus. Later on (1992) he also described a new 
species of Emesinae (Reduviidae) named Empicoris electricus Thom. From subfossil Dominican copal, one more species from the genus Empicoris named E. copal Popov (1987a) was also described. Earlier, Wygodzinsky (1966) referred to another specimen of Empicoris from the Chiapas amber (Thomas, 1992) but offered no further elaboration. An unnamed emesin from Dominican amber was figured in the work of Schlee (1980); it was described later on as Malacopus wygodzinskyi (Popov, 1987b) as well as Alumeda dominicana Pop., Alumeda nigricans Pop., and Alumeda antilliana Pop. (Popov, 1989). Two more undescribed assassin bugs from the subfamily Emesinae are also known to me. As for Mexican amber, Hurd et al. (1962) mentioned the first plant bugs (Miridae) from the plesiomorphic subfamily Isometopinae and also Aradidae, Dipsocoridae and Hebridae. The only known fossil hebrid bug (Hebridae) was described from Chiapas amber as Stenohebrus glaesarius by Polhemus (1995), which was mentioned before by Andersen (1982) and later on illustrated by Poinar (1992). Also described from Mexican Chiapas amber was the first known fossil termite bug Termitaradus protera Poinar and Doyen (1992) belonging to the extremely modified heteropterans of the aradoid family Termitaphididae. Five more specimens of T. protera were found in a single piece of Mexican amber (Poinar and Heiss, 2011). Recent termitaphidids are living only in the nests of termites and found in the Neotropical, Ethiopian, Oriental and Australian regions. Later on, three more species of termite bugs (Termitaradus avitinquilinus,
T. mitnicki, T. dominicanus) were described from Dominican amber (Grimaldi and Engel, 2008; Engel, 2009; Poinar and Heiss, 2011).

\section{Description of the new species (Systematics)}

Family: Reduviidae Latreille, 1807

Subfamily: Emesinae Amyot \& Serville, 1843

Tribe: Ploiariolini Van Duzee, 1916

Genus: Alumeda Popov, 1989

Type species: Alumeda nigricans Popov, 1989: 3

\section{Alumeda solorzanokraemerae sp. nov}

Figs. 1-4

Holotype: female from Mexican amber, Chiapas, Simojovel area. Deposited in the Staatliches Museum für Naturkunde, Stuttgart, Inv.-Nr. MX-260-X. Body is considerably damaged.

Coloration - General coloration black and ochraceous, in vivo pale parts perhaps straw yellow. Head and thorax black, almost devoid of light stripes. Antennae ochraceous, without black rings. Scutellum and metanotum completely black. Fore legs ochraceous; coxa and trochanter completely black, femur 1 with four and tibia 1 with two rings in basal half (Figure 3). Middle and hind legs ochraceous; femur 2 with 5 more or less equal rings, basal part of tibia 2 with one subbasal ring; femur 3 with 4 equal narrow rings.

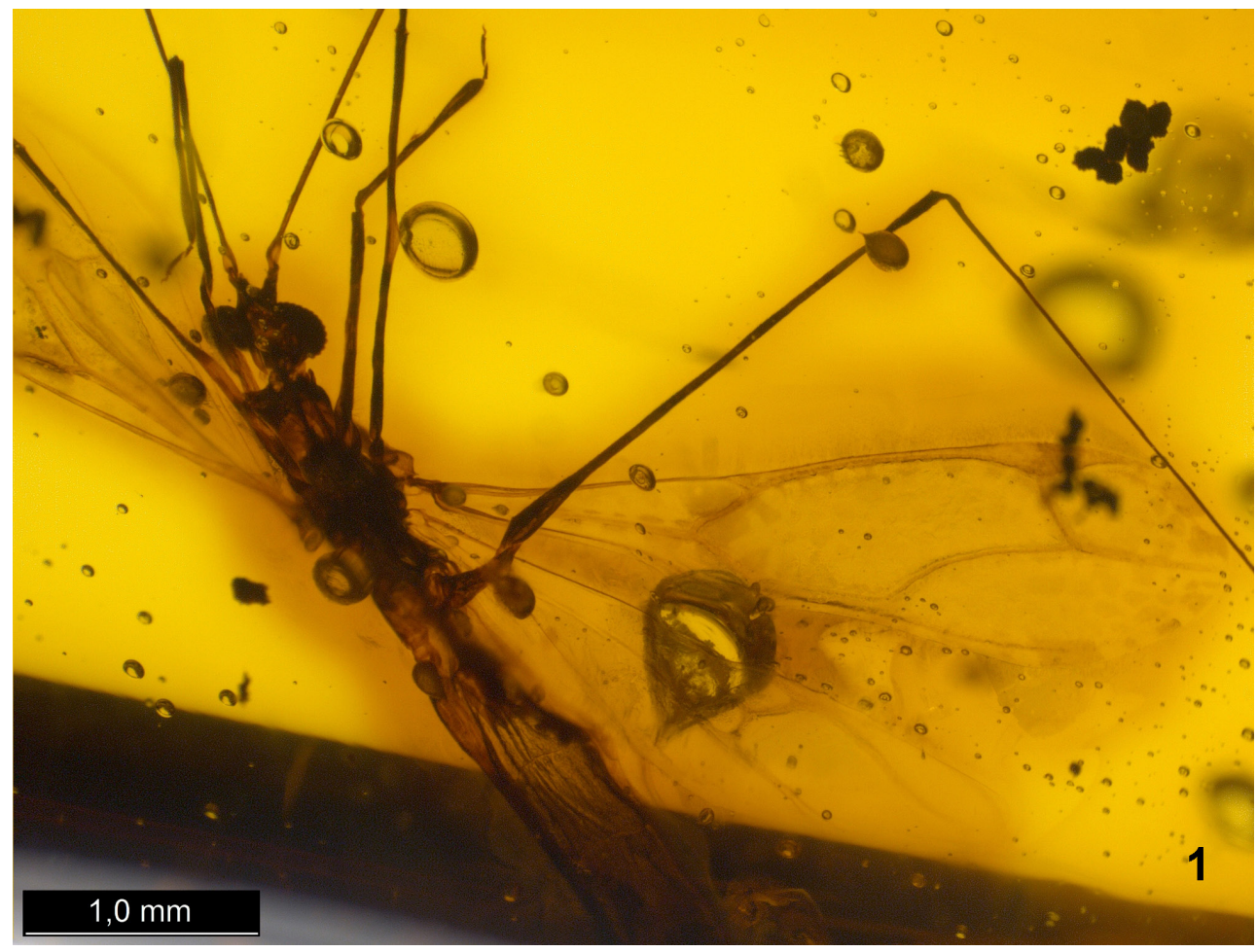

Figure 1. Alumeda solorzanokraemerae sp. nov., dorsal view (photo by Dmitry E. Shcherbakov). 


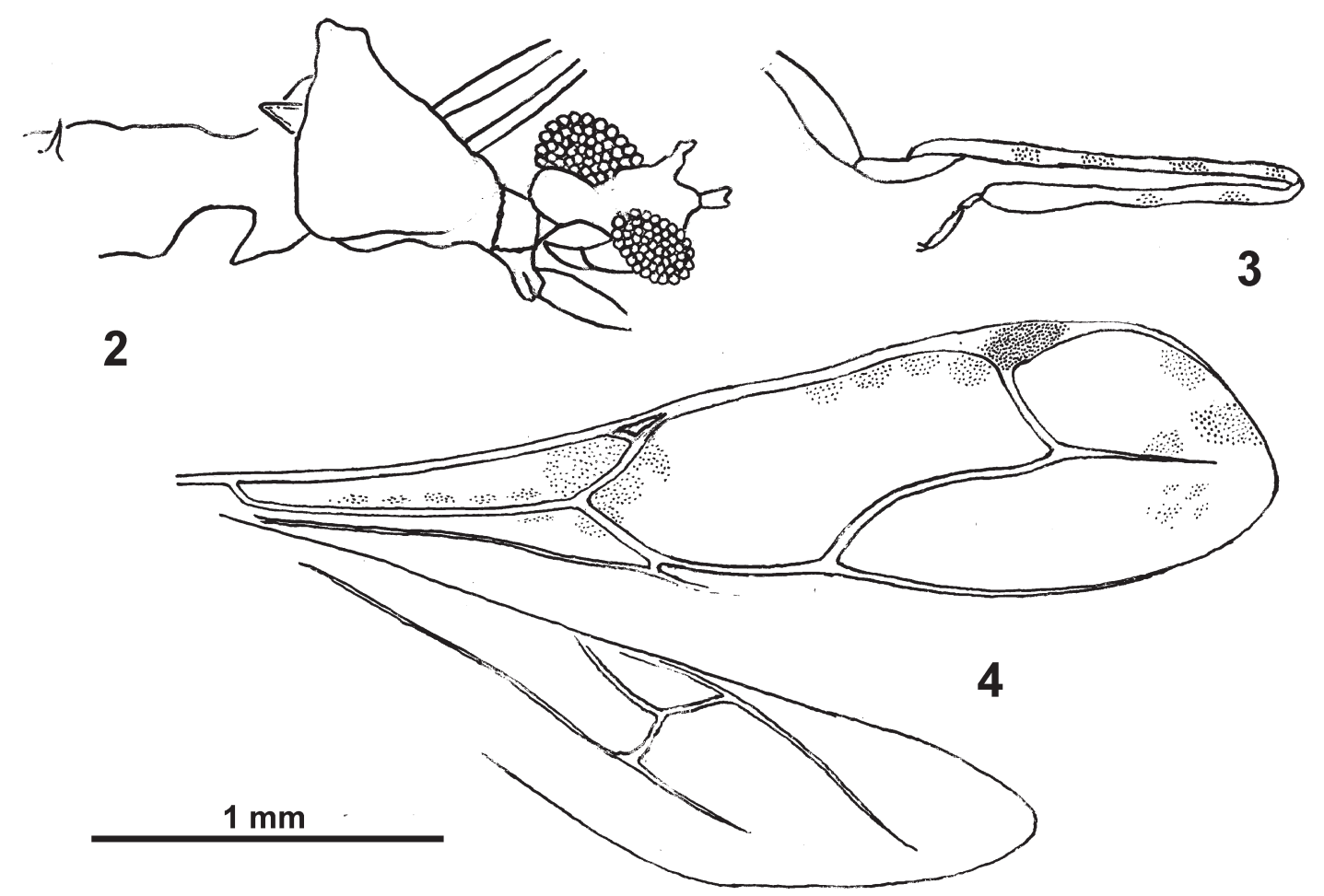

Figures 2-4. Alumeda solorzanokraemerae sp. nov.: 2 - forebody; $\mathbf{3}$ - foreleg; $\mathbf{4}$ - fore- and hind wings. Scale $1 \mathrm{~mm}$ in all figures.

Forewings semihyaline, with numerous pale spots, as in Figure 4; pterostygma mostly dark with light apex. Hind wing colorless. Abdomen almost entirely ochraceous, in vivo perhaps brown; spine of abdominal segment ochraceous.

Head - Head rather strongly deformed as in Figure 2; anteocular region most probably equal to posterior one. Eyes large, globular. Antennae bare; ratio of antennomeres 1-4 as 27:42:19:8.

Thorax - Thorax strongly deformed as in Figure 2; pronotum as in Figure 2; surface smooth, hairless. Posterior lobe very short, $4.5 \mathrm{x}$ longer than anterior lobe.

Legs - Fore legs slender (Figure 3), clothed with numerous very short, dense, delicate hairs much shorter than diameter of coxa or femur. Coxa 1 rather slender, 8 times as long as wide; length ratio of femur 1 and tibia 1 as 10:7.5. Ratio of coxa 1, femur 1 and tibia 1 as 12:21:15. Ratio of middle and hind femora as 7:10, both bare; fore tarsi 2-segmented.

Wings - Fore wing apically rounded, 3.6 times as long as wide; pattern and venation as in Figure 2; distance from apex of pterostigma to tip of wing $\mathbf{2 . 5} \mathrm{x}$ as long as distance from apex of pterostigma to insertion of M; discal cell $\mathbf{2 . 8} \mathrm{x}$ as long as its maximum width, apical portion clearly pointed; independent basal part of anterior border of discal cell as long as $1 / 3^{\text {rd }}$ of its fused part with anterior margin of wing. Venation of hind wing complete; $\mathrm{M}-\mathrm{Cu}$ very long (Figure 4).

Spines - Spine of abdominal segment 1 very short and slender (Figure 2).

Measurements. Length up to apices of forewings 4.6 mm; length of head $0.3 \mathrm{~mm}$, width $055 \mathrm{~mm}$; maximum length of forewings $3.6 \mathrm{~mm}$, width $1.0 \mathrm{~mm}$; length of head $0.3 \mathrm{~mm}$, width $0.55 \mathrm{~mm}$; length of pronotum $0.62(0.11+$ $0.5)$.

Etymology. Named after the well-known German paleontologist Mónica M. Solórzano Kraemer for her important contribution in studying of the insect fauna from Mexican amber.

Remarks. The genus Alumeda Popov was only known only from the synchronous Miocene Dominican amber and three extinct species: A. nigricans Pop. (type generic species), A. dominicana Pop. and A. antilliana Pop. (Popov, 1989). The fossil species described above seems to be related to Alumeda nigricans Popov (especially in the wing characters). The main distinguishing feature of this new species is an extraordinarily short pronotum (posterior lobe x 4.5 longer than anterior lobe); it also differs by having a somewhat longer discal cell. (2.8x), as well as by a different proportion for the basal independent part of the discal cell and fused portion of the anterior margin of wing.

\section{Key to species of the genus Alumeda Popov, 1989 (based on forewings)}

1. (6) Pterostygma rather long, distance from apex to tip of wing not more than $3 \mathrm{x}$ as long as distance from apex of pterostigma to insertion of M; apical portion of discal cell somewhat pointed. 

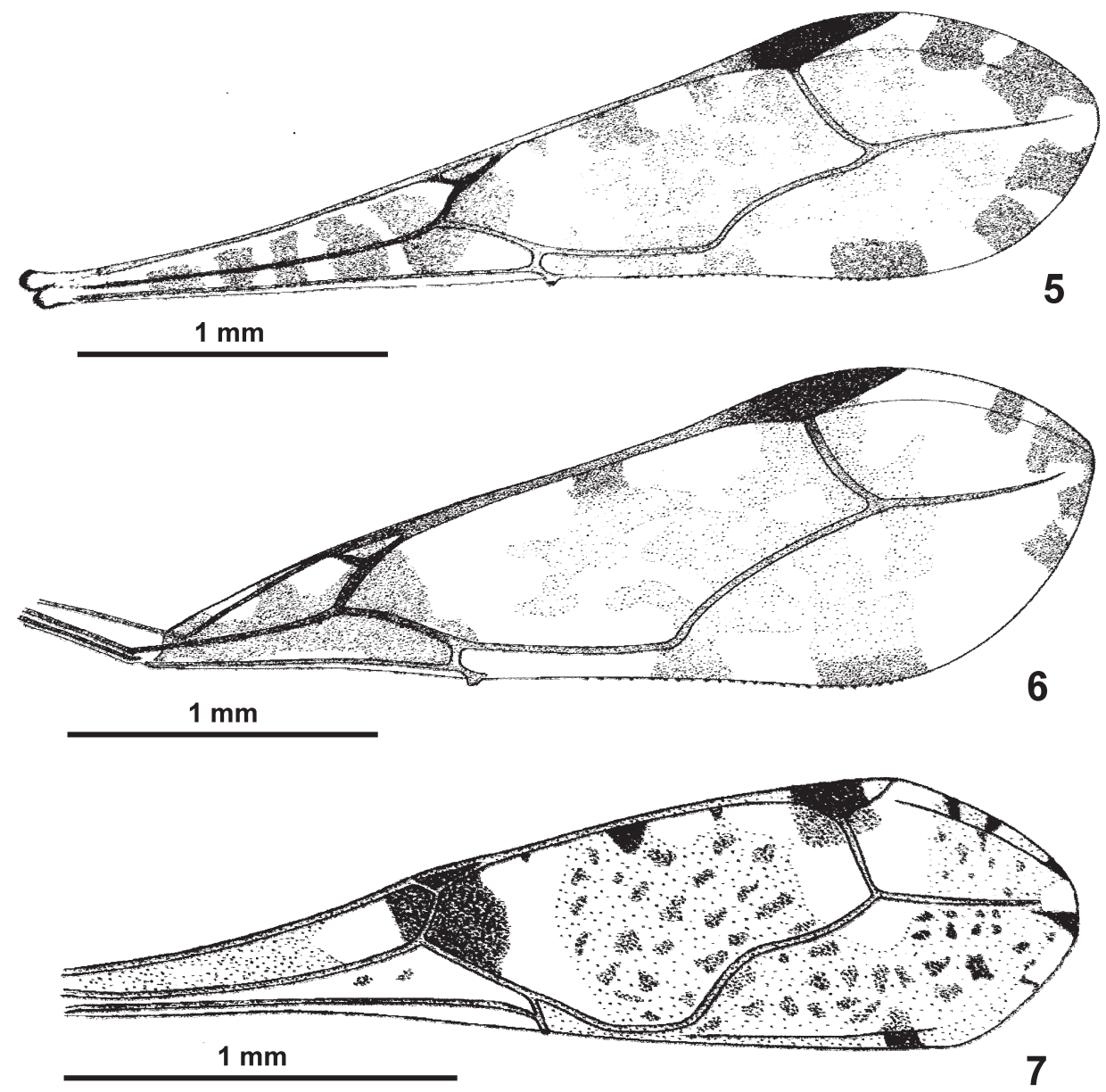

Figures 5-7. Alumeda spp. from Dominican amber, forewings (after Popov, 1989); 5 - A. dominicana Popov; 6 - A. nigricans Popov; 7 - A. antilliana Popov. Scale $1 \mathrm{~mm}$ in all figures.

2. (3) Forewings narrow, $5 \mathrm{x}$ as long as wide; discal cell $3 \mathrm{x}$ as long as wide, its basal independent part $1 / 4^{\text {th }}$ of its fused portion with anterior margin of wing; wing pattern as in Figure 5... A. dominicana Pop.

3. (2) Forewings wider, slightly over $3.5 \mathrm{x}$ as long as wide; discal cell less than $3 \mathrm{x}$ as long as wide.

4. (5) Discal cell $2.5 \mathrm{x}$ as long as wide; its basal independent part $1 / 5^{\text {th }}$ of its fused portion with anterior margin of wing; wing pattern as in Figure 6... A. nigricans Pop.

5. (4) Discal cell $2.8 \mathrm{x}$ as long as wide; its basal independent part $1 / 3$ of its fused portion with anterior margin of wing; wing pattern as in Figure 4... A. solorzanokraemerae sp.n.

6. (1) Pterostygma short, distance from its apex to tip of wing $4 \mathrm{x}$ as long as distance from apex of pterostigma to insertion of $\mathrm{M}$; apical portion of discal cell not pointed; wing pattern as in Figure 7... A. antilliana Pop.

\section{Acknowledgements}

I am grateful to Dr. Günter Bechly (Staatliches Museum für Naturkunde, Stuttgart, Germany) who allowed me access to the Emesinae specimen in his care and to Mónica Solórzano Kraemer for the invitation to present a paper for this special volume "Mexican amber". I wish to thank Alex Evsyunin (Zoological Centre, Tula, Russia) for the illustrations and Dmitri Shcherbakov (Borissiak Paleontological Institute RAS) for a help in the preparation of this paper. I thank Ernst Heiss (Innsbruck, Austria) and an anonymous reviewer for useful comments on an earlier draft of the manuscript.

\section{References}

Andersen, N.M., 1982, The semiaquatic bugs (Hemiptera, Gerromorpha). Phylogeny, adaptations, biogeography and classification: Entomograph, 3, 1-455, Scandinavian Science Press, Klampenborg, Denmark. 
Berggren, W.A., Van Couvering, J.A., 1974, The late Neogene: Palaeogeography, Palaeoclimatology, Palaeoecology, 16, 1-216.

Cobben, R. H., 1971, A fossil shore-bug from the Tertiary amber of Chiapas,Mexico (Heteroptera, Saldidae): University of California, Publications in Entomology, 63, 49-56.

Engel, M.S., 2009, A new termite bug in Miocene amber from the Dominican Republic (Hemiptera, Termitaphididae): ZooKeys, 45, 61-68.

Frost, S.H., Langenheim, R. L., 1974, Cenozoic reef biofacies, Tertiary larger foraminifera and scleractinian corals from Chiapas, Mexico: Northern Illinois University, Press, DeKalb.

Grimaldi, D.A., Engel, M.S., 2008, A Termite Bug in Early Miocene Amber of the Dominican Republic (Hemiptera: Termitaphididae): American Museum, Novitates, 3619, 1-10.

Hurd, P.D., Smith, R.F., Durham, J.W., 1962, The fossiliferous amber of Chiapas, Mexico: Ciencia, 21(3), 107-118.

Langenheim, J.H., 1966, Botanical source of amber from Chiapas, Mexico: Ciencia, 24, 201-210.

Poinar, G.O. Jr., 1992, Life in amber: Stanford University Press, Palo Alto, California, 1-350.

Poinar, G. O. Jr., 1999, Cenozoic fauna and flora in amber: Estudios del Museo de Ciencias Naturales Alava, 14, Número especial 2, $151-154$.

Poinar, G.O. Jr., Doyen, J.T., 1992, A fossil termite bug, Termitaradus protera sp.n. (Hemiptera: Termitaphididae) from Mexican amber: Entomologica Scandinavica, 23(1), 89-93.

Poinar, G.O. Jr., Heiss, E., 2011, New Termitaphididae and Aradidae (Hemiptera) in Mexican and Dominican amber: Palaeodiversity, 4, 51-62, Stuttgart.

Polhemus, J.T., 1995, A new genus of Hebridae from Chiapas amber (Heteroptera): Pan-Pacific Entomologist, 71(2), 78-81.

Popov, Y.A., 1987a, Synopsis of the Neotropical bug genus Malacopus Stål, with the description of a new fossil species from Dominican amber (Heteroptera: Reduviidae, Emesinae): Stuttgarter Beitrage zur Naturkunde, Serie B (Geologie und Paläontologie), 130, 1-15.
Popov, Y.A., 1987b, A new species of the bug genus Empicoris Wolff from Dominican amber, with the redescription of E.nudus McAtee and Malloch (Heteroptera: Reduviidae, Emesinae): Stuttgarter Beitrage zur Naturkunde, Serie B (Geologie und Paläontologie), 134, 1-9.

Popov, Y.A., 1989, Alumeda n.g., a new bug genus erected for three fossil species from Dominican amber (Heteroptera: Reduviidae, Emesinae): Stuttgarter Beitrage zur Naturkunde, Serie B (Geologie und Paläontologie), 150, 1-14.

Schlee, D., 1980, Bernstein-Raritäten: Staatliches Museum für Naturkunde, Stuttgart, 1-88.

Solórzano Kraemer, M.M., 2007, Systematics, palaeoecology, and palaeobiogeography of the insect fauna from Mexican amber: Palaeontographica, Abteilung A: Paläozoologie-Stratigraphie, 282, $1-133$.

Solórzano Kraemer, M.M., 2010, Mexican Amber, in Biodiversity of fossils in amber from the major world deposits. (ed. D.Penney), 42-56.

Thomas, D.B., 1988, Fossil Cydnidae (Heteroptera) from the OligoMiocene amber of Chiapas, Mexico: Journal of the New York Entomological Society, 96 (1), 26-29.

Thomas, D.B., 1992, A fossil Empicoris Wolff (Reduviidae: Heteroptera) from Mexican amber with remarks on the phylogenetic status of the fossil genus Alumeda Popov: Journal of the New York Entomological Society, 100 (4), 535-539.

Wygodzinsky, P.W., 1959, A new hemipteran (Dipsocoridae) from the Mexican amber of Chiapas: Journal of Paleontology, 33, 853-854.

Wygodzinsky, P.W., 1966, A monograph of the Emesinae (Reduviidae, Hemiptera): Bulletin of the American Museum of Natural History, $133,1-614$.

Manuscript received: October 15, 2014.

Corrected manuscript received: January 10, 2015.

Manuscript accepted: January 12, 2015. 